\title{
Justice Scalia: \\ Tenured Fox in the Democratic Hen-House?
}

\author{
Jane Marriott* \\ University of London
}

\begin{abstract}
This paper examines Justice Scalia's approach to campaign finance adjudication, in particular his skepticism of legislative motive. Three distinct strands of skepticism are identified: power-grabbing, incumbent-bracing and speech-preventing. As regards democracy Justice Scalia is identified as being caught in definitional dilemma whereby his campaign finance jurisprudence appears to serve a particular vision of democracy, which is, itself, the identifiable creature of his approach to constitutional adjudication. Ultimately, it is argued that, whilst a liberal dose of mistrust of government might well be warranted in cases concerning the devices of democracy, in the task of scrutinising campaign finance regulation and reform, a strong argument emerges for suspicion of judicial motives too since there is as much danger to democracy posed by the tenured fox as by the incumbent one.
\end{abstract}

\section{CONTENTS}

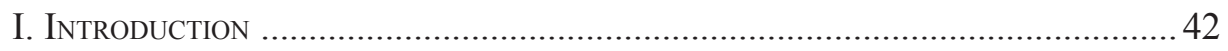

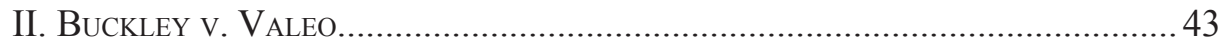

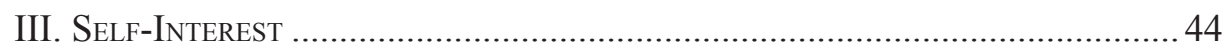

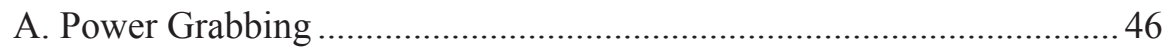

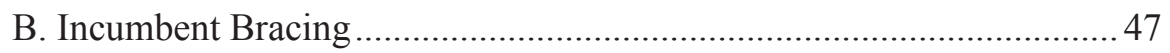

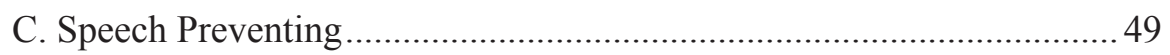

IV. Judging Democracy: Paradox and Dilemma ........................................... 52

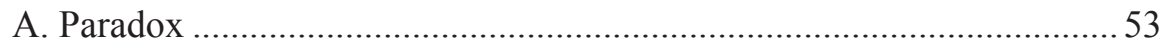

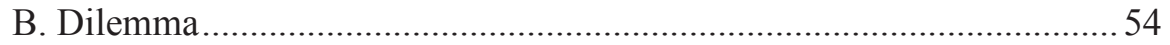

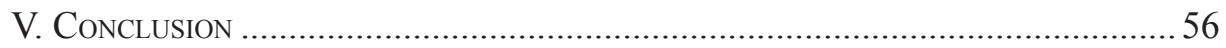

* Lecturer in Law, School of Law, Royal Holloway, University of London. 


\section{INTRODUCTION}

In the context of the $40^{\text {th }}$ anniversary of Buckley $v$. Valeo, ${ }^{1}$ a recent line of authority spurning electoral reforms, ${ }^{2}$ an election cycle in which expenditure on campaigning exceeded $\$ 7$ billion, ${ }^{3}$ and the death of Justice Scalia, it was perhaps unsurprising that 2016 came to be widely regarded as offering an opportunity for deliverance from a Supreme Court majority seemingly bent on deregulation of the campaign finance system and in denial of the consequences of its actions. Justice Scalia belonged to the gang of five - a 'conservative on campaign finance' cohort also comprising Chief Justice Roberts and Justices Alito, Kennedy, and Thomas. Commentators have condemned the resulting disfigurement of American elections, with Justice Scalia in receipt of much academic, political and public opprobrium, despite having rarely authored a majority campaign finance opinion for the Court. ${ }^{4}$ It must be acknowledged that, as in other areas of Supreme Court adjudication, Justice Scalia's dissents and concurrences on controversies in campaign finance tended to draw fire rather more readily than those of others. Given his judgments' often stark concision and potent bite, such was the nature of things. ${ }^{5}$ It must also be acknowledged that, despite the undoubted transformative power of elections, the Trump victory is unlikely to liberate the Court from the grip of its conservative Justices, or from agenda led, market driven, laissez-faire campaign finance adjudication. The new President's recognition of a "broken" system and promise to "drain the swamp" might be welcome but the rhetoric is wholly disconnected from the reality that, on regulation and reform, the Supreme Court's role is determinative.

Given the prevalence of the 5-4 split in campaign finance cases, it is self-evident that having to fill an empty seat on the Supreme Court bench could "flip national rules for American elections by 180 degrees." Currently, however, the possibility of an about turn appears remote. Instead, with a probable, and probably increasingly acute, lurch to the right as a result of successive Trump appointments to the Supreme Court, 2016 may prove a false dawn for campaign finance reform. At the time of writing it is too early to say but, for the new administration, the issue may be set low on the agenda and, given what has been achieved under the existing regulatory regime, the political

424 U.S. 1 (1976).

See Randall v. Sorrell, 548 U.S. 230 (2006), Federal Election Comm'n v. Wisconsin Right to Life, 551 U.S. 449 (2007), Citizens United v. Federal Election Comm'n, 558 U.S. 310 (2010).

3 Projected figures as at 10 November 2016. See https://www.opensecrets.org/overview/ cost.php (accessed 3/7/17), showing total spending as $\$ 6,917,636,161$, comprised of $\$ 4,266,514,050$ for Congressional races and $\$ 2,651,122,110$ for the Presidential race.

4 See, e.g., Erwin Chemerinsky, Not a Free Speech Court, 53 Ariz. L. Rev. 723 (2011).

5 On Justice Scalia's writing style, see Charles Fried, Manners Makyth Man: The Prose Style of Justice Scalia, 16 Harv. J. L. \& PuB. Pol'y, 529 (1993); Kapgan, Of Golf and Ghouls: The Prose Style of Justice Scalia, 9 J. Leg. Writing Inst. 71 (2003).

6 First Presidential Debate, Sep. 26, 2016.

7 https://www.donaldjtrump.com/press-releases/trump-pledges-to-drain-the-swamp (last visited March 7, 2017).

8 Richard L. Hasen, After Scalia: The Future of United States Election Law, School of Law, U.C. Irvine Sch. of Law Research Paper Series No 2016-14, available at https://papers.ssrn.com/sol3/papers.cfm?abstract_id $=2763713$. 
will may well turn out to be lacking; even if it is broke, don't fix it. Considering the circumstances, part of Justice Scalia's jurisprudential bequest could turn out to be his contribution to a conservative blueprint for campaign finance adjudication that may endure for decades to come. His campaign finance jurisprudence might recently have been dammed with faint praise as merely "rhetorically effective" but the question that should perhaps be posed is whether it needs also be appreciated for its clear ideological grounding and internal jurisprudential consistency? Those hallmarks are, after all, largely absent from the broad sweep of either the Court's campaign finance adjudication which, since Buckley, has "swung like a pendulum," 10 or Justice Scalia's judicial responses to matters of election law generally, which lack the same settled characteristics. ${ }^{11}$ Here, Justice Scalia's campaign finance jurisprudence is examined, in particular its skepticism of legislative motive. Three distinct strands of skepticism are identified: power-grabbing, incumbent-bracing and speech-preventing. Ultimately, it is argued that, while a liberal dose of mistrust of government might well be warranted in cases concerning the devices of democracy, in the task of scrutinising campaign finance regulation and reform, a strong argument emerges for suspicion of judicial motives too since there is as much danger to democracy posed by the tenured fox as by the incumbent one.

\section{BuCKLEY V. VALEO}

In Buckley v. Valeo, in opposition to the strongly worded dissent of Justice White maintaining that unlimited election spending constituted "a mortal danger" against which "effective preventive and curative steps" 12 should be taken, the Supreme Court invalidated key provisions of the Federal Election Campaign Act 1974 (FECA), Congress's post-Watergate reforms of money in politics. The decision defined the parameters of constitutionally permissible regulation of election campaigns and has set the tone for campaign finance adjudication for the last forty years. For present purposes, Buckley's key holdings were fourfold. Firstly, whilst limits on contributions were upheld, limits on election expenditures were struck down as unconstitutional because they imposed direct inhibitions on political speech and thus fell foul of the First Amendment. Secondly, a governmental interest in equalizing the relative ability of all voters to influence the outcome of elections was not sufficiently compelling to justify the burden placed on First Amendment freedoms as a result: "the concept that government may restrict the speech of some elements of our society in order to enhance the relative voice of others is wholly foreign to the First Amendment." 13 Thirdly, the only governmental interest compelling enough to support campaign finance regulation was an interest in preventing corruption or the appearance of corruption. Fourth, and finally, FECA's

\footnotetext{
$I d$. at 2 .

10 Richard L. Hasen, No Exit? The Roberts Court and the Future of Election Law, 57 S.C. L. Rev. 669, 673 (2006).

11 See Hasen, supra note 8.

12424 U.S. 1259 (1976).

$13 \quad I d$. at 49.
} 
disclosure provisions were upheld, being deemed instrumental in providing the electorate with information regarding the provenance and deployment of campaign funds, deterring actual corruption and avoiding the appearance of corruption and detecting violations of campaign finance laws.

Prior to Buckley, the Supreme Court had experienced only "glancing encounters"14 with the kinds of conflicts presented by campaign finance regulation. Buckley was unique because, in the context of adjudicating on devices of democracy, it forced the Court to confront the tensions between equality and liberty, individual and collective welfare, the integrity of the democratic system and legislative self-interest, and state and judicial power. Polsby states of the much vilified decision that there had "never been a more treacherous case for balancing interests and harmonizing values" 15 and notes that the Court's opinion "has more than its share of dark places and contradictions." 16 Shortly after his appointment to the Supreme Court in 1986, however, Justice Scalia declared, in Austin v. Michigan, that "Buckley should not be overruled, because it was entirely correct." ${ }^{17}$ Heavily dependent on the tenets of Buckley, ${ }^{18}$ Justice Scalia's dissent in Austin provided the principal, first-person articulation of positions that would become characteristic of his campaign finance jurisprudence, namely: faith in disclosure as the least worst infringement of individuals' liberties in regulating money in politics, ${ }^{19}$ a narrow construction of corruption, a correspondingly expansive construction of free speech, a healthy regard for the abilities of citizens to make informed choices without government interference in fundamental political rights in order for them to do so, ${ }^{20}$ and a skepticism of legislators' motives. ${ }^{21}$

\section{SELF-INTEREST}

According to Ortiz, campaign finance regulation is motivated by four explicit concerns: improving the day to day operation of legislative politics, improving the quality of political discussion and debate, protecting democratic processes from corruption, and maintaining political equality. ${ }^{22}$ The regulatory exercise meets

14 Daniel D. Polsby, Buckley v. Valeo: The Special Nature of Political Speech, Sup. Cт. Rev. 5 (1976).

15 Id. at 42.

16 Id. at 14.

17 Austin v. Michigan Chamber of Comm., 494 U.S. 652, 683 (1990) (Scalia, J., dissenting). Later, Justice Scalia would join Justice Thomas in maintaining that Buckley should be overruled because it "provided insufficient protection to political speech": Randall v. Sorrell, 548 U.S. 230, 230 (2006) (emphasis added).

18 Explicitly acknowledging the importance of the "seminal" case of Buckley v. Valeo in Federal Election Comm'n v.Wisconsin Right to Life, 551 U.S. 449, 485 (2007).

19 Joining Justice Kennedy in dissent, stating " $t]$ he more narrow alternative of recordkeeping and funding disclosure is available." Austin v. Michigan, 494 U.S. 652, 707 (1990).

20 Id. at 695 ("the people are not foolish but intelligent and will separate the wheat from the chaff").

21 Id. at 660 and 669.

22 Daniel R. Ortiz, The Democratic Paradox of Campaign Finance Reform, 50 STAN. L. REv. 893, 897-899 (1998). 
little ideological resistance, being deemed "amply justified in principle" ${ }^{23}$ yet, in practice, campaign finance regulation "raises the spectre of governmental efforts to promote the interests of existing legislators." 24 Thus, whilst each component of a given regulatory framework might be explicitly directed at ridding politics of the malign influence of money it may also implicitly benefit incumbent legislators in possession of "linedrawing power" 25 and an overwhelming desire to remain in office. Re-election appears to be the one policy on which they all agree. ${ }^{26}$ The regulation of campaign finances may thus present a distinctive situation which appears to run counter to the adversarial nature of partisan politics due to an apparent, albeit variable, political consensus both on the need to purify the system and the means by which purification is to be achieved. ${ }^{27}$ The assumption may not, therefore, be made that regulations governing the raising and spending of money for political purposes are neutral or necessarily constructed with the health and integrity of democratic processes in mind, irrespective of the fact that they may be so labelled. ${ }^{28}$ The wider impact of self-interested campaign finance regulation can be severe, resulting in uncompetitive elections, a stacked and ossified democratic system with representatives "planted in office for perpetuity." ${ }^{29}$ It is apparent, therefore, that the regulation of campaign finance can all too easily result in the promotion of political expediency over democratic principle where the state becomes an "institutionalized structure of support, sustaining insiders while excluding outsiders" ${ }^{\prime 30}$ which, itself, "counts as a problem of corruption." ${ }^{31}$ In campaign finance adjudication, there has been explicit and longstanding judicial recognition that both existing regulations and proposals for reform may be designed as mechanisms of power-holding or maintenance, intended to "serve the interests of the 'ins' ... in resisting the incursions of the 'outs'." 32 The Court of Appeals in Buckley, for example, noted that "[ $\mathrm{t}] \mathrm{he}$ wiles of ambitious office seekers and their supporters are not easily cabined." ${ }^{33}$ In similar fashion, rather than simply expressing deference in the face of what were ostensibly "policy decisions" on regulating campaign finances, Justice Scalia

23 Cass R. Sunstein, Political Equality and Unintended Consequences, 94 Colum. L. Rev. 1390, 1390 (1994).

24 Id. at 1400.

25 Nathaniel Persily, In Defense of Foxes Guarding Henhouses: The Case for Judicial Acquiescence to Incumbent Protecting Gerrymanders, 116 HaRv. L. Rev. 649, 658 (2002).

26 Michael Johnston, The Incumbent Protection Act of 2002? Politics Under the New Campaign Finance Law, Institute of Advanced Study, June 2003 - available at https://www. sss.ias.edu/files/papers/paper15.pdf.

27 Generally speaking, western liberal democratic campaign finance controls comprise a combination of all or some of expenditure limits, contribution ceilings, disclosure provisions and an enforcement body.

28 For a discussion of this phenomenon, see Bradley A. Smith, Faulty Assumptions and Undemocratic Consequences of Campaign Finance Reform, 105 YALE L.J. 1049 (1996). See also John Samples, The Fallacy of Campaign Finance Reform (2006) and Lillian R. BeVier, Campaign Finance Reform: Specious Arguments, Intractable Dilemmas, 94 Colum. L. Rev. 1258 (1994).

29 Persily, supra note 25, at 654

30 Richard S. Katz \& Peter Mair, Changing Models of Party Organization and Party Democracy: The Emergence of the Cartel Party, 1 PARTY Politics 5, 16 (1995).

1 Johnston, supra note 26, at 1.

32 Buckley v. Valeo, 519 F.2d 821, 843 (D.C. Cir. 1975).

33 Id. 
consistently proved extremely sensitive to the possibility of legislation "whose temporary political importance may threaten to eclipse respect for inconvenient individual liberties", ${ }^{34}$ despite evidence that, over the last thirty years, incumbency advantage has dwindled due to rising levels of party loyalty, the nationalization of electoral politics and closer articulation between presidential and congressional elections. ${ }^{35}$ Highlighting the weaknesses of the "self-interest" argument for restricting campaign finance regulation and reform, Hasen maintains that it is both axiomatic $^{36}$ that politicians might favor campaign finance legislation and inevitable that the Court's campaign finance hawks would latch on to the un-nuanced idea of campaign finance laws as a "protection racket" ${ }^{37}$ since this would best serve the deregulatory agenda. Notwithstanding his recognition that legislative motivation is often inexplicit and difficult to discern, ${ }^{38}$ his philosophy that the meaning of the text was determinative ${ }^{39}$ and belief that, in any event, Justices should be "governed by laws, not by the intentions of legislatures" 40 throughout his tenure, and with an enthusiasm that perhaps exceeded the political reality, Justice Scalia consistently floated the idea of legislators' self-interest as a danger to democracy where it informed campaign finance rules. In the courtroom, where scrutiny might reveal the threat of self-interest having crystallized into legislative output and political practice, Justice Scalia's "hard-charging skeptic"41 jurisprudence reveals three distinct manifestations of legislators' self-interest in campaign finance regulation: power grabbing, incumbent bracing and speech preventing.

\section{A. Power grabing}

In the power grabbing sense Justice Scalia's judgments depict legislators as disingenuous, moralizing imperialists requiring careful judicial supervision, and from whom the electorate and electoral processes need the protection provided by the Court. The path to campaign finance reform may be littered with "the very best of announced objectives (dictators promise to bring order, not tyranny), and often with the very best of genuinely intended objectives (zealous policemen conduct unlawful searches in order to put dangerous felons behind bars)" ${ }^{42}$ but leads to "governmental abridgement of liberty" 43 nonetheless. Dissenting in Austin v.

T.R.S. Allan, The Limits of Parliamentary Sovereignty, PuB. L. 614, 620-621 (1985).

35 Gary C. Jacobsen, It's Nothing Personal: The Decline of Incumbency Advantage in US House Elections 77 J. Polit. 861 (2015).

36 Richard L. Hasen, Plutocrats United: Campaign Money, the Supreme Court and the Distortion of American Elections 147 (2016).

$37 \quad$ Id.

38 "I cannot say for certain that many, or some, or even any, of the Members of Congress who voted for this legislation did so not to produce fairer campaigns but to mute criticism of their records and facilitate re-election." McConnell v. Fed. Election Comm'n, 540 U.S. 93, 262 (2003).

39 Antonin Scalia, A Matter of Interpretation: Federal Courts and the Law (1997).

40 Conroy v. Aniskoff, 507 U.S. 511, 519 (1993).

${ }_{41}$ BobBauer,JusticeScaliaandCampaignFinance: APuzzle, http://www.moresoftmoneyhardlaw. com/2016/02/justice-scalia-campaign-finance-one-puzzle/ (Last visited March 7, 2017).

42 Austin v. Michigan Chamber of Comm., 494 U.S. 652, 692 (1990).

43 Id. 
Michigan Justice Scalia argued that the Court's support for the Michigan Campaign Finance Act's prohibition on corporations using treasury money in independent expenditures supporting or opposing candidates running for state office eliminated organisations from public debate and, thus, permitted the "always dominant" power of government firstly to be augmented and, secondly, deployed "to impoverish the public debate." ${ }^{44}$ In similar fashion, in Citizens United v. Fed. Elections Comm ' $n{ }^{45}$ where the Court held that the federal government, under cover of the Bipartisan Campaign Reform Act (BCRA), could not prevent corporations from spending money to support or denounce individual candidates in elections, Justice Scalia challenged the idea that such speech could be prohibited because, in the view of government, it fostered "moral decay" or failed to serve "public ends," the natural consequence then being "no limit to the Government's censorship power." 46

\section{B. INCUMBENT BRACING}

The second way in which legislators' self-interest was employed by Justice Scalia to undercut state and federal governments' attempts at campaign finance regulation and reform was through its depiction as a means of bracing incumbents against the efforts of challengers to gain office. In a number of cases spanning twentyfive of his thirty year tenure, the perceived character flaws and shortcomings of incumbents were scathingly identified, and the statistically and anecdotally welldocumented advantages of incumbency ${ }^{47}$ made clear. In Austin Justice Scalia declared that "the incumbent politician who says he welcomes full and fair debate is no more to be believed than the entrenched monopolist who says he welcomes full and fair competition," ${ }^{48}$ and in McConnell he posed the question whether, through the provisions of the BCRA, it was "accidental ... that incumbents raise about three times as much 'hard money' - the sort of funding generally not restricted by this legislation - as do their challengers?" 49 The self-interest issue does not just feature disparities in the accumulation of cold hard cash, however. Often regulation is commended by legislators on the basis of its even-handedness in treating both challengers and incumbents equally but, even then, and perhaps in particular then,

Id. at 694.

558 U.S. 310 (2010).

46 Id. at 391. In this instance provisions of the BCRA prevented the showing of a documentary seeking to discredit Hillary Clinton's 2008 bid for presidential candidacy on the basis that it was an election communication.

47 See, e.g., Gary W. Cox and Jonathan N. Katz, Why Did the Incumbency Advantage in U.S. House Elections Grow? 40 Am. J. PoL. ScI. 478 (1996); Richard L. Hasen, Entrenching the Duopoly: Why the Supreme Court Should Not Allow the States to Protect the Democrats and Republicans from Political Competition Sup. CT. Rev. 331 (1997); Stephen Ansolabehere \& James M. Snyder, The Incumbency Advantage in U.S. Elections: An Analysis of State and Federal Offices, 1942-2000, 1 Election L. J. 315 (2002); David R. Mayhew, Incumbency Advantage in U.S. Presidential Elections: The Historical Record, 123 Polit. ScI. Q. 201 (2008); Alexander Fouirnaies \& Andrew Hall, The Financial Incumbency Advantage: Causes and Consequences, 76 J. Polit. 711 (2014).

48 Austin v. Michigan Chamber of Comm., 494 U.S. 652, 692 (1990).

49 McConnell v. Fed. Election Comm'n, 540 U.S. 93, 249 (2003). 
it would be prudent to question "incumbents" notions of healthy campaigns" 50 since those notions might be conditioned by a desire to perpetuate the advantages of incumbency and, in practice, may lead to the suppression of challengers' actual speech or opportunities for it. ${ }^{51}$ In Austin Justice Scalia addressed the deficiencies of one such statute, saying of the Campaign Finance Act that "perhaps it was trying to ensure 'balanced' presentation because it knows that with evenly balanced speech incumbent officeholders generally win" ${ }^{52}$ - because of other advantages that accompany possession of public office, such as profile - whilst acknowledging that, ultimately, "any restriction upon a type of campaign speech that is equally available to challengers and incumbents tends to favor incumbents." 53 This brings us to the issue of speech prevention as a consequence of self-interest. It is here, in First Amendment territory, where Justice Scalia's deployment of self-interest as a counter to regulation and reform is most compelling, expressing doubt that America's "healthy democratic system can survive the legislative power to prescribe how much political speech is too much, who may speak, and who may not." ${ }^{34}$ It must, however, be said that Justice Scalia's commitment to skepticism, whilst enduring, was neither total nor complete.

It has been indicated that, in campaign finance cases, Justice Scalia exhibited a high degree of vigilance where legislators' self-interest was likely to manifest. As has also been indicated, he supported disclosure of the sources of campaign contributions as an unquestioned good. McIntyre v. Ohio Elections Commission ${ }^{55}$ concerned a prohibition on the distribution of anonymous campaign literature contained in Ohio's Elections Commission Code, which the Court found unconstitutional as it violated the First Amendment's freedom to publish anonymously. Justice Scalia disagreed. Bauer notes that where, at the hands of Justice Scalia, legislators would usually "come in for rough treatment as self-interested actors who are not to be trusted, as political wolves in policy-makers' clothing" 56 by contrast, in McIntyre the views of elected legislators were much better received with the Justice urging the Court to have a "decent regard for the practical judgment of those more familiar with elections than we are" and for "universal and long-established American legislative practice." ${ }^{57}$ It may be argued, therefore, that self-interest - at least in the sense of desiring a particular outcome operates on more than merely the legislative level, appearing to be present in Justices' judgments too since here it was deployed by Justice Scalia to support the principle and practice of disclosure, something of which he approved. Certainly, his mode of constitutional adjudication has been labelled "essentially opportunistic," 58 through adopting precedents and approaches when they produced a result he wanted. This

50 Fed. Election Comm'n v. Wisconsin Right to Life, 551 U.S. 449, 503 (2007).

51 Randall v. Sorrell 548 U.S. 230, 268 (2006), Justice Scalia joining Justice Thomas dissent, stating "[i]n practice, this restriction will generally suppress more speech by challengers than by incumbents".

Austin, 494 U.S. 652, 692 (1990).

Mc Connell, 540 U.S. 93, 249 (2003).

Austin, 494 U.S. 652, 695 (1990).

514 U.S. 344 (1995).

Supra note 41.

514 U.S. 344, 381 \& 377 (1995).

58 Nelson Lund, Antonin Scalia and the Dilemma of Constitutional Originalism, 11 George Mason Legal Studies Research Paper No. LS 16-36. (Dec. 5, 2016). Available at SSRN: https://ssrn.com/abstract=2880578. 
"disingenuous" decision-making and resulting jurisprudence is criticized as the result of value choices masquerading as neutral judicial methodology. .9

\section{SPEECH PREVENTING}

There can be no doubt as to the centrality of the First Amendment to United States' democracy: "Speech is an essential mechanism of democracy, for it is the means to hold officials accountable to the people. The right of citizens to inquire, to hear, to speak, and to use information to reach consensus is a precondition to enlightened self-government and a necessary means to protect it." 60 To that end, Sunstein has expressed the belief that "properly designed campaign finance legislation may be fully compatible with the system of free expression, insofar as those measures promote the goal of ensuring a deliberative democracy among political (though not economic) equals." ${ }^{61}$ As we have seen, however, for Justice Scalia significant and pressing issues remained regarding the interests and motivations - both foreground and background - informing that proper design. It is argued here that, in circumstances where legislators' motives are likely to be mistrusted, no "design" under scrutiny - whether presented as "proper" or not - should be taken at face value. Indeed the very concept of a "proper" design should set alarm bells ringing since it suggests the fulfilment of some, or somebody's, vision of campaign finance. Given Justice Scalia's mistrust of legislative motivation, and his adoption of Buckley's expansive reading of the First Amendment in the sphere of campaign finance, there can be little surprise at his resistance to efforts to condition or curb free speech in that setting, notably, and controversially, in Citizens United and Wisconsin Right to Life, irrespective of how "proper" (in the Sunstein sense of being oriented to the functioning of a deliberative democracy) the design appeared to be. The design at issue on this occasion was the BCRA, in the "genesis and consequences" of which Justice Scalia found a "wondrous irony" since "the institutions it was designed to muzzle - unions and nearly all manner of corporations - for all the corrosive and distorting effects of their immense aggregations of wealth, were utterly impotent to prevent the passage of this legislation that forbids them to criticize candidates (including incumbents). ${ }^{\prime 62}$

Citizens United, a conservative, not for profit advocacy group, questioned the constitutionality of $\S 441 \mathrm{~b}$ of the BCRA which, in short, prohibited corporations from spending general funds on electioneering communication or speech expressly advocating the election or defeat of a candidate within 60 days of an election. Under strict scrutiny as it implicated First Amendment issues, in the Court's majority opinion $\S 441 \mathrm{~b}$ failed to further a compelling government interest and, in treating the speech of corporations differently from the speech of others (namely, natural persons) violated First Amendment neutrality as to speakers and points of view.

59 Erwin Chemerinsky, The Jurisprudence of Justice Scalia: A Critical Appraisal, 22 U. Haw. L. Rev. 385, 385 (2000). See also, Miranda McGowan, Do as I Do, Not as I Say: An Empirical Investigation of Justice Scalia's Ordinary Meaning Method of Statutory Interpretation, 78 Miss. L.J. 129, 150 (2008).

60 Citizens United, 558 U.S. 310, 339 (2010).

${ }_{61}$ Sunstein, supra note 23, at 1400 (emphasis added).

62 Wisconsin Right to Life, 551 U.S. 449, 508 (2007). 
Against the strongly-worded opinion of the four dissenting Justices expressing concern that unfettered spending by corporations risked their over-influence and distortion of elections the Court's conservative majority found that non-profit corporations' independent election expenditures could not be restricted. ${ }^{63}$ The decision removed Austin's shackles, freeing corporations and unions to spend unlimited amounts of money on electioneering and other political activities as long as they were undertaken independently of a party or candidate.

In Austin, with Justice Scalia in dissent, Justice Thurgood Marshall had delivered the Court's majority ruling that the government could ban electoral expenditures by business corporations in order to prevent them from deploying "resources amassed in the economic marketplace" with the purpose of "obtaining an unfair advantage in the political marketplace." ${ }^{4}$ Justice Scalia rejected the idea of government being permitted to exclude actors from the marketplace of ideas, on the basis that, irrespective of how rational and egalitarian it might seem on the face of it, "government cannot be trusted to assure ... the 'fairness' of political debate" ${ }^{65}$, in that case finding it "entirely obvious" that the "object of the law we have approved today is not to prevent wrongdoing but to prevent speech."

Here, in Citizens United, some twenty five years later, Justice Scalia dismissed the majority opinion in Austin as based on an "Orwellian" view "that too much speech is an evil that the democratic majority can proscribe." ${ }^{.67}$ In later defending the expansion of Citizens United's principles in Wisconsin Right to Life, Justice Scalia identified the Court's "most important constitutional task" 68 as ensuring freedom of political speech, further noting that "when a statute creates a regime as unworkable and unconstitutional as today's effort ... it is our responsibility to decline enforcement." ${ }^{69}$ The Court has been censured for the practical consequences of Citizens United, which opened the floodgates to moneyed interests rather more widely than before. ${ }^{70}$ For his part, however, and measured against the ability of political parties to engage in aggregate speech, Justice Scalia thought it better to "celebrate rather than condemn" the addition of corporate speech to the public debate since "to exclude or impede" it would "muzzle the principal agents of the

63 The majority was also concerned that corporations should not be granted the same free speech rights as human beings. Under the guidance of the conservative majority, Citizens United has been extended to embrace for-profit corporations, labor unions and other associations. See Wisconsin Right to Life v. Fed. Election Comm'n, 551 U.S. 449 (2007).

64 Austin v. Michigan Chamber of Comm., 494 U.S. 652, 659 (1990), (citing Fed. Election Comm'n v. Massachusetts Citizens for Life, 479 U.S. 238 (1986)).

$65 I d$. at 680.

$66 \quad I d$. at 694.

67 See Austin, 494 U.S. 652, 678 (1990). Farber notes that "[i]t is precisely this tendency to overregulate speech activities that requires constitutional protection for speech" - see Daniel A. Farber, Free Speech Without Romance: Public Choice and the First Amendment, 105 Harv. L. Rev. 554, 561 (1991). "Orwellian" is also used by Justice Scalia to describe Roe v. Wade: "[T] o portray Roe as the statesmanlike 'settlement' of a divisive issue, a jurisprudential Peace of Westphalia that is worth preserving, is nothing less than Orwellian." Planned Parenthood v. Casey, 505 U.S. 833, 995 (1992).

68 See Wisconsin Right to Life, 551 U.S. 449, 503 (2007).

69 Id.

70 See, e.g., Robert C. Post, Citizens Divided: Campaign Finance Reform and the ConstiTUTION 2014 and Richard L. Hasen, Citizens United and the Illusion of Coherence, 109 Mich. L. Rev. 581 (2011). 
modern free economy," ${ }^{, 71}$ those agents being corporations rather than politicians or the people. It has been argued that the outcome of Citizens United is best explained as "representing a triumph of the libertarian over the egalitarian vision of free speech." 72 In truth, since Buckley, the majority of campaign finance cases could, in broad terms, be explained in that way. The libertarian vision, Sullivan notes, "serves the end of liberty by checking government overreaching into the private order." 73 This would seem to chime with Justice Scalia's preferences for broadly construed freedom of speech and cynically approached legislative initiatives in campaign finance cases.

Basham and Polhill, arguing that elected representatives should be excluded from campaign and election rule-making and regulation, state that there is unlikely to be an improvement in political competition unless "the incumbent fox ends his tenure as guardian of the democratic henhouse" 74 but, whatever the concerns over the self-interest of legislators, an equivalent and equally difficult set of issues arises when courts, rather than legislatures, are permitted to determine the fate of campaign finance regulation. Do courts, insulated from politics as they supposedly are (but clearly are not) possess the requisite institutional and democratic competence to allow themselves to overrule the conclusions of legislators on political realities? In the immediate aftermath of Buckley, Leventhal took the view that, where such realities are involved and there is a substantial possibility that a statute might improve the health of democracy, it should be upheld and judged on its results. ${ }^{75}$ Judicial deference in such cases may therefore be "extremely appropriate ... since legislators have first-hand knowledge." ${ }^{\prime 76}$ This was the approach taken by the Supreme Court in four campaign finance cases of the early 2000s, at the tail end of the Rehnquist Court. The cases - identified by Hasen as the "New Deference Quartet"

71 Citizens United, 558 U.S. 310, 393(2010). Justice Scalia unconvincingly attempted to depict corporations and political parties in the same guise, arguing that both could speak for individuals who had associated together, that the nature of the speech does not change, have less value or lose its potency according to its source of funding and that, because the First Amendment did not mention "speakers", but concerned "speech", no category of speakers could be excluded.

72 Kathleen M. Sullivan, Two Concepts of Freedom of Speech, 124 Harv. L. Rev. 143, 145 (2010).

$73 \quad$ Id. at 155.

74 Uncompetitive Elections and the American Political System, Cato Institute Policy Analysis No. 547, 30 June 2005 at 15.

75 Harold Leventhal, Courts and Political Thickets, 77 Colum. L. Rev. 345, 346 (1977).

76 Marlene Arnold Nicholson, Campaign Financing and Equal Protection, 26 STAN. L. REv. 815, 823 (1974),

77 See Hasen, supra note 10 at 674. The cases comprising the New Deference Quartet are Nixon v. Shrink Missouri PAC, 528 U.S. 377 (2000), Fed. Election Comm'n v. Colorado Repub. Fed.Campaign C'tee, 528 U.S. 377 (2000), McConnell v. Fed. Election Comm'n 540 U.S. 93 (2003) and Fed. Election Comm'n v. Beaumont 539 U.S. 146 (2003). Hasen identifies Nixon v. Shrink Missouri as the most significant of the four cases: in respect of contribution limits, it raised the threshold for constitutional challenge of contribution limits and reduced the level of scrutiny for review of contribution limits. In addition, a more expansive definition of corruption was adopted, thus easing government's justification for campaign finance regulations, as well as proof of corruption being made easier to evidence 674-75. 
Buckley's dogma but, in so doing, exhibited "increasing incoherence" when set against its rather more definite standards, due to the "strained reasoning" employed to read an equality rationale into campaign finance jurisprudence which forcefully disavowed it. As might be imagined, Justice Scalia did not embrace "new deference", which would, in any case, fall to a reaffirmation of Buckley by the Roberts Court. As such, the characterization of "deference quartet" case McConnell as a "precarious ... victory for reform" ${ }^{80}$ seems apposite and of wider relevance and application than to McConnell alone.

Schauer maintains that campaign finance cases should not be treated as a means of deciding between "competing visions of democracy." ${ }^{11}$ Instead, he claims that they are cases concerning "the devices of democracy [which] may have political valence and reflect substantive political values [but] are ... in some rough and ready way, procedural." ${ }^{82}$ Thus it is necessary to "treat the question of "Who Decides?' as distinct from the question of what is to be decided." ${ }^{83}$ Only in this way can we "recapture the possibility that one could simultaneously believe campaign finance reform to be a good idea while believing that legislative decisions about campaign finance reform were suspect." ${ }^{84}$ The basis for Schauer's argument is that "[a]1l of the devices of democracy are antecedent to substantive democratic decisions" and are "likely to be misdecided if subject to actual and substantively influenced democratic processes." ${ }^{85}$ Legislative decisions about campaign finance regulations thus "merit the protections inherent in constitutionalization" since "if debates about the procedures to be employed ... might be driven by concerns about which procedures would best facilitate the substantive agendas of various groups, then we might prefer to give the courts ... a larger role to play," 86 though turning the courts into "trustbusters of political cartels" $" 87$ is, itself, thick with difficulty.

\section{Judging Democracy: Paradox and Dilemma}

Persily urges judicial intervention in campaign finance cases, where "crafty linedrawing" ${ }^{88}$ risks thwarting majority will and threatens to undercut the idea of meaningful choice for the electorate through eliminating or reducing the possibility of competition for control of the legislature. In assessing the role played by judges

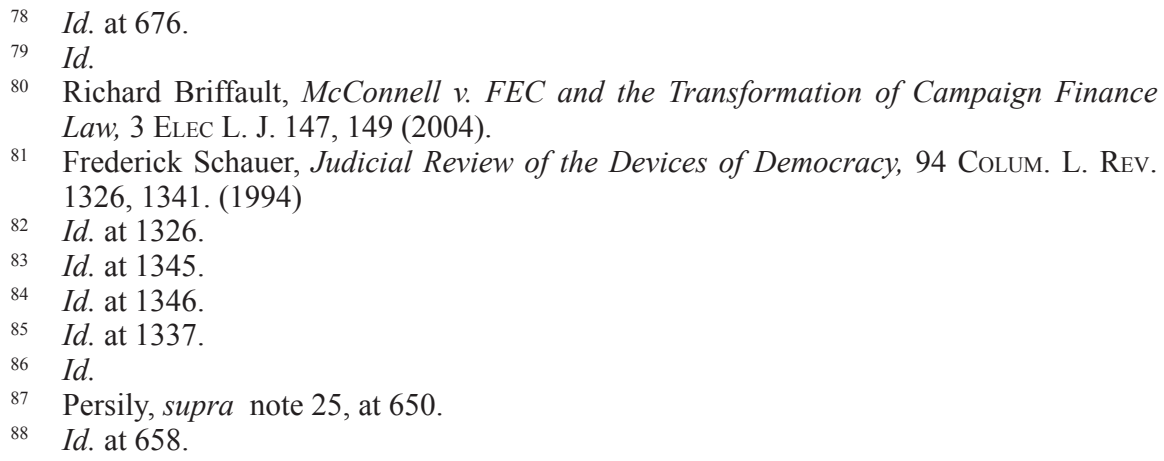


in election law cases, Ortiz identifies what he calls the "democratic paradox" 89 and Ringhand a "definitional dilemma." would be trapped by the paradox, yet every Justice would appear to be caught in the definitional dilemma.

\section{A. PARADOX}

Ortiz argues that campaign finance regulation - of whatever hue, and premised upon whatever basis - should be functionally redundant. A central normative assumption of democracy is that voters are civically competent; a central normative assumption of campaign finance regulation is that voters are not civically competent:

To the extent Americans are ... engaged, informed voters who carefully reason through political arguments, we hardly need the kind of protection that campaign finance regulation affords us. Even if one side of a political race dramatically outspends the other, voters can be relied on to sort through the merits and ultimately decide on the right candidate or policy.... [T] he equality-protecting and other rationales underpinning most forms of campaign finance regulation are premised on doubts about voters' civic capabilities. This is the democratic paradox of campaign finance reform. ${ }^{91}$

Of course, where a democracy appears not to be functioning correctly, or the people seem to be making the "wrong" choices, legislative correction might be attempted, which may, in turn, require consideration by or intervention from the Supreme Court which, according to Ortiz, "manipulates its assumptions about individual political behavior in a way that should trouble us." 92

Ortiz identifies two distinctive approaches taken to voters' civic competence by the Supreme Court. One approach conceives of the voter as a "civic smarty" and the other as a "civic slob." ${ }^{93}$ A "civic smarty" is engaged in active, wellinformed deliberation. By contrast the "civic slob" is passive, and ill-informed as a result. If a Justice conceives of voters as civic slobs - even if that conception is unarticulated - that will almost inevitably dispose that Justice towards campaign finance regulation as a means of better ensuring a well-functioning deliberative democracy. It then becomes impossible for that Justice to see voters as anything but civic slobs since their rehabilitation to civic smarties would remove the raison d'etre for the regulation and, by extension, the precedential framework and what it supports. By contrast, Justices who envisage voters as civic smarties will bear no pre-disposition to regulation, trusting in the system and its users to deliberate and register preferences as required. For Ortiz "[d]eregulationists have had the better

89 Daniel R. Ortiz, The Democratic Paradox of Campaign Finance Reform, 50 STAN. L. Rev. 893 (1998).

90 Lori Ringhand, Defining Democracy: The Supreme Court's Campaign Finance Dilemma, 56 Hastings L. J. 77 (2004).

91 Nicholson, supra note 76, at 895.

92 Daniel R. Ortiz, The Engaged and the Inert: Theorizing Political Personality Under the First Amendment,81 VA. L. R. 1, 4 (1995).

93 Id. 
of the debate because ... champions of campaign finance regulation can never argue their case successfully. To make their argument work, the regulationists must recognize what they have been reluctant to admit: that we are at least partly civic slobs." $" 94$

As indicated previously, Justice Scalia's approach to adjudicating campaign finance exhibited a healthy regard for the abilities of citizens to make informed choices without government interference in fundamental political rights in order for them to do so. As is also apparent, Justice Scalia favored no more than minimum regulation in the campaign finance sphere since that was least intrusive of important democratic rights. On the face of it, therefore, Justice Scalia's night-watchman approach to campaign finance regulation, combined with his faith in the people as civic smarties inclined to make the right choices, meant that he was not trapped by the paradox. He might, however, have fallen victim to the definitional dilemma. This is neither unexpected nor unusual since, by Ringhand's yardstick, seemingly any Justice holding a view about what makes democracy, and adjudicating accordingly, would be so placed. In what follows, it will be argued that, given Justice Scalia's concerns about legislators' self-interest, his expansive reading of free speech and his approach to constitutional interpretation, while he would escape Ortiz's democratic paradox through placing trust in voters' civic competence, he would easily be caught by Ringhand's definitional dilemma.

\section{B. DILEMMA}

If, on any reasonable understanding of democracy, campaign finance regulation contributes to producing democratic institutions that are essentially undemocratic, it may be thought reasonable that judges should intervene to remedy that defect. On this view, intervention is justifiable in the interests of democracy itself but may be problematic if judicial conceptions of democracy and the rights required to sustain it are divergent. Adjudicating campaign finance places the judiciary in what Ringhand claims is an unacknowledged and overlooked "democracy defining dilemma" 95 where the rights they are being asked to protect are both contested and undefined. Given the lack of consensus on the scope and nature of the rights implicated in campaign finance cases, in order to provide a framework or foundation for adjudication, a judge must envisage, but need not articulate explicitly, a conception of democracy on which to base his or her opinion. Judicial conceptions of democracy are, thus, implicit in and underpin Justices' campaign finance opinions. They are inextricably intertwined with the Justices' own democratic views and values - what Ortiz calls "submerged normative judgments" $" 96$ - because, importantly, they are chosen rather than being constitutionally compelled ${ }^{97}$ (although the Justices may present them that way).

For Ringhand, the definitional dilemma has three consequences. Firstly, she argues, campaign finance cases come to rest on "unchallenged" yet "deeply

Ortiz, supra note 92 , at 5.

Nicholson, supra note 76, at 77.

Ortiz, supra note 92, at 11.

Nicholson, supra note 76, at 80 ("Moreover, they have been able to do this without persuasively demonstrating, or often even arguing, that their preferred definition of democracy is in any way constitutionally compelled."). 
contested and controversial"98 definitions of democracy, the preservation of which mandates constitutional restraints on legislative experimentation. ${ }^{99}$ Although these restraints are the product of beliefs in concepts about which there is disagreement and division, they are made to appear both legitimate and necessary. Secondly, "disputed" and "shifting" judicial assumptions about democracy lend a certain incoherence and abstruseness to campaign finance jurisprudence. ${ }^{100}$ Thirdly, because the democracy-defining dilemma is not confronted by the judiciary, the provenance of the rights being asserted is uncertain, which in turn means that issue of whether campaign finance regulation is constitutionally mandated is obscured. ${ }^{101}$ By way of example, in campaign finance cases, as has been indicated, Justice Scalia exhibited a high degree of vigilance where legislators' self-interest was likely to manifest. As has also been indicated, he supported disclosure of the sources of campaign contributions as an unquestioned good. We have seen that in McIntyre $v$ Ohio Elections Commission ${ }^{102}$ the views of elected legislators were unquestioningly accepted by the dissenting Justice Scalia, on the bases of established legislative practice and legislators' practical familiarity with elections. ${ }^{103}$ While Justice Scalia's dissent in McIntyre may be viewed as evidence of a judicial philosophy of restraint, and one which gives elected branches the final say, in deploying legislative expertise to support his position on disclosure, it might also be argued to reveal exactly the kind of judicial shifting and expediency in adjudication to which Ringhand refers. It clearly does not sit with a professed skepticism of legislative motive in campaign finance cases.

Current campaign finance jurisprudence, as subject to the definitional dilemma, superficially bears the hallmarks of activist liberal decision-making, whereby Justices seek to preclude governmental intrusion into the rights and liberties guaranteed by the Constitution. Accordingly, where campaign finance decisions, viewed simplistically, seemingly demonstrate Supreme Court justices striking at legislation which interferes with constitutional rights they may, in fact, reveal the Court's conservatives cleaving to principles that narrow and restrict those rights as they apply to ordinary people, while simultaneously enlarging them for the wealthy, and erecting a barrier to important electoral, economic and social reforms. Kairys ${ }^{104}$ claims that both a liberal and a conservative judiciary will see itself as protecting freedom and the other as permitting unwarranted governmental intrusion. The difference lies in their respective stances as to what kind of government activity constitutes, and counts as, permissible interference. Thus, where liberals favor less intrusive government in the area of individual autonomy and personal freedom, and more intrusive government in economic regulation and electoral or democratic reforms, conservatives demonstrate antithetical tendencies. They will most likely support measures aimed at "compelled conformity," 105 yet balk at

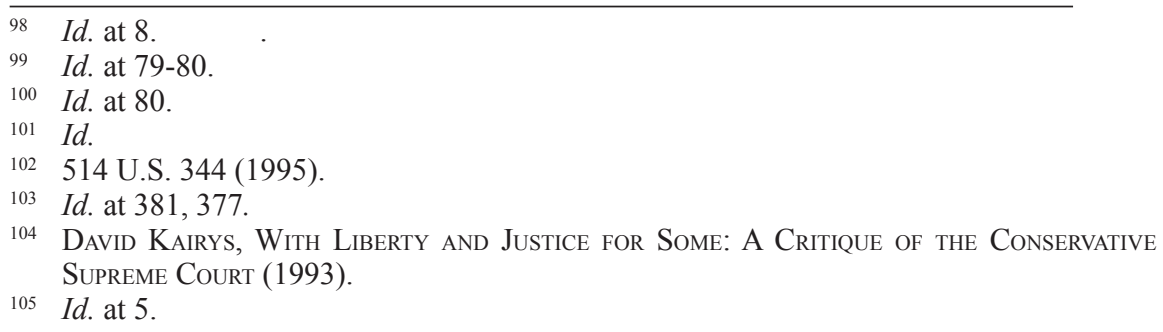


attempted governmental intrusion into the operation of markets, property rights and the advantages of wealth. In this sense, tenured judges may have as much impact on the campaign finance system as incumbent politicians. That impact need not engender change, however. The stasis produced by ideological divergence between regulationists and deregulationists is well illustrated by McConnell whose reading of campaign finance adjudication, after Citizens United but prior to Justice Scalia's death, was that the majority of the Justices condemned Buckley's distinction between contributions and expenditures, but for different reasons, and would deal with it in different ways. The conservative wing of the Court, naturally including Justice Scalia, he argues, would eliminate the distinction entirely by affording constitutional protection to contributions as well as expenditures, whereas the liberal wing would erase the distinction by removing the constitutional protection afforded to independent expenditures. This "produces a standoff." 106 On McConnell's reading, therefore, the death of Justice Scalia has reduced the likelihood of constitutional protection being extended beyond Buckley's limits since the conservative wing is diminished. For Justice Scalia, however, it was "not ... a liberal versus conservative issue" but "an issue of constitutional interpretation." 107

\section{CONCLUSION}

Ortiz provides three possible explanations for Buckley's holding that election expenditure limits are offensive to the First Amendment: that, irrespective of the government's interest, the First Amendment simply forbids control of speech in that way; ${ }^{108}$ that money follows popular support and, thus, poses no overall threat to political processes; ${ }^{109}$ that, because it adds information and points of view to the ideas marketplace, money can only enhance, rather than undermine, individual decision-making. ${ }^{110}$ The first reason, claims Ortiz, "rests only on textual fundamentalism or on the policy judgment that the dangers of the congressional remedy were worse than the disease."111

In describing his approach to the task of constitutional interpretation, Justice Scalia declared that he was "first of all a textualist, and secondly an originalist."112 In his own view textualism means that "you don't care about the intent and I don't care if the framers of the Constitution had some secret meaning in mind when they adopted its words." ${ }^{113}$ Although a disinterest in intent might seem at odds with an interest in legislative self-interest in campaign finance cases, the originalist in Justice Scalia enabled intent to be measured in some rough, ready and anecdotal

106 Michael W. McConnell, Reconsidering Citizens United as a Press Clause Case, 123 YALE L. J. 412, 456 (2013).

107 Justice Antonin Scalia, A Theory of Constitution Interpretation, Catholic University of America, Washington DC, address delivered Oct. 18, 1996.

108 Ortiz, supra note 92, at 14.

109 Id.

110 Id.

111 Id.

112 Justice Antonin Scalia, supra note 107.

113 Id. 
way. ${ }^{114}$ Moreover, in the campaign finance sphere, two fundamental and longaccepted premises also underlie Justice Scalia's approach. First is the idea that the Bill of Rights was intended to prevent government from encroaching upon the liberties of citizens: "[t]he premise of our Bill of Rights ... is that there are some things - even some seemingly desirable things — that government cannot be trusted to do" 115 and, second, the broad assumption is that "there is no such thing as too much speech." ${ }^{116}$ Placed together with Ortiz's assessment of Buckley, and in the context of an expansive reading of speech, ${ }^{117}$ a particular reading of democracy, which Ortiz traces to Buckley, would inevitably lead to the consistency in campaign finance cases that Justice Scalia's campaign finance jurisprudence, for the most part, exhibits. It led that way because jurisprudential coherence and consistency emerges more readily out of broad premises and deregulation in a manner that it cannot arise where extensive regulation and fine market adjustments provide the basis for democracy's processes and operation.

114 In Austin, "I am confident, in other words, that Jefferson and Madison would not have sat at these controls; but if they did they would have turned them in the opposite direction;" "but then there is the special element of corporate wealth: What would the Founders have thought of that?;" "This is not an argument that our democratic traditions allow" and looking back to the late 18th century for proof that corporations should enjoy the same free-speech rights as individuals and that the press carried corporate speech by way advertisements as well as news stories on their front pages, 494 U.S. 652, 693 (1990).

115 Id. at 692.

116 McConnell v. Fed. Election Comm'n, 540 U.S. 93, 259 (2003).

117 In Citizens United, Justice Scalia's textual originalism provided the foundation for the most expansive of readings of the First Amendment in the campaign finance sphere, even in the context of an expansion of Buckley's expansive premises. 